\title{
ANÁLISE DE GENES QUE SE MOSTRARAM AMPLIFICADOS EM AMOSTRAS DE ADENOMA PLEOMORFO E CARCINOMA EX-ADENOMA PLEOMORFO PELA TÉCNICA DE CGH-ARRAY
}

\author{
Wellington Lima Sabino*, João Figueira Scarini, Reydson Alcides De Lima Souza, Érika Egal, Álfio José Tincani, \\ André Del Negro, Luiz Paulo Kowalski, Ana Krepischi, Albina Altemani e Fernanda Viviane Mariano
}

\section{Resumo}

O carcinoma ex-adenoma pleomorfo (CXAP) é uma neoplasia agressiva, cuja patogênese ainda não está esclarecida. Nos últimos anos, muitos estudos sugeriram que a transformação maligna estava relacionada com o acúmulo de alterações genéticas em um adenoma pleomorfo (AP) pré-existente. Neste trabalho, analisamos os genes que se encontraram amplificados pela técnica de Hibridização Genômica Comparativa em microarranjo (array Comparative Genomic Hibridization - CGH array) em amostras de AP residual e CXAP em diferentes fases da carcinogênese (intracapsulares, minimamente invasivos e francamente invasivos) subdivididos quanto ao subtipo histológico. Em resumo, nossos resultados mostraram 489 genes amplificados nas amostras estudadas, sendo que $287(58,7 \%)$ estavam relacionados apenas ao CXAP enquanto que $144(29,5 \%)$ ao AP residual. Vinte e nove $(5,9 \%)$ destes genes eram comuns entre AP residual e CXAP.

Palavras-chave: adenoma pleomorfo, carcinoma ex-adenoma pleomorfo, alterações genéticas, CGH-arrray

\section{Introdução}

O adenoma pleomórfico (AP) é a neoplasia benigna mais comum das glândulas salivares. Em raros casos pode sofrer transformação maligna para um carcinoma ex-adenoma pleomórfico (CXAP), neoplasia maligna agressiva que normalmente cursa com mau prognóstico, metástases e óbito. Nos últimos anos, a patogênese do CXAP vem sendo atribuída ao acúmulo de distúrbios genéticos no AP pré-existente. No entanto, não existe confirmação se há um gene alvo comum envolvido em todos os subtipos histopatológicos ou se os fatores decisivos para a transformação maligna são específicos. Diante disso, este trabalho se propôs a analisar os genes amplificados em amostras de AP residual e CXAP por meio da técnica de $\mathrm{CGH}$-array em trabalho prévio de Pós-doutorado (Processo FAPESP 2011/23366-5).

\section{Resultados e Discussão}

Os achados inéditos em AP residual e CXAP resultantes no trabalho de Pós-Doutorado supracitado necessitam ser complementados com técnicas precisas que confirmem o papel destes genes na patogênese destas neoplasias. Para isso, os resultados encontrados por $\mathrm{CGH}$-array precisaram ser analisados antes da validação.

Por meio da ferramenta virtual InteractiVenn (http://www.interactivenn.net/) agrupamos os genes amplificados tanto em AP residual e CXAP. Ao final, selecionamos com base em todas as análises de repetições, os genes candidatos à validação. Os resultados desta análise inicial estão apresentados neste trabalho.

Dos 489 genes amplificados nas amostras estudadas, notamos que mais da metade dos genes (287 de 489 - 58,7\%) estavam relacionados ao CXAP, ressaltando $\mathrm{o}$ acúmulo de alterações genéticas na contraparte maligna analisada. Vinte e nove $(5,9 \%)$ destes genes eram comuns entre AP residual e CXAP.
Conforme esperado, em relação ao grau de invasão do CXAP, houve aumento no número de genes amplificados à medida que o grau de invasão e agressão aumentava: 8 genes relacionados ao CXAP intracapsular, 59 ao CXAP minimamente invasivo e 280 ao francamente invasivo, cujo comportamento é geralmente de alto grau, com consequências clínicas importantes. Além disso, foram observados que entre os grupos do AP residual e do CXAP intracapsular (com comportamentos clínicos semelhantes) dois genes foram comuns: ERRB2 e GRB7.

Em relação ao subtipo histológico, os fenótipos ditos de alto grau histológico apresentaram mais amplificações (320 genes amplificados) do que àqueles considerados de baixo grau (129 genes). Três destes genes eram comuns entre os grupos de alto e baixo grau: HMGA2, RPSAP52 e LOC100129940.

Em relação as repetições, MYNC, ERBB2, BRIP1 e HMGA2 foram os genes amplificados mais repetidos nos AP residuais. Por outro lado, HMGA2, ERRBB2, CDK12, RPSAP52, LOC100129940, LOC100507250 foram os genes com mais repetições em CXAP.

\section{Conclusões}

Nossos resultados sugerem que HMGA2, ERRB2, RPSAP52, GRB7, CDK12, MYNC e BRIP1 podem ter papel fundamental na carcinogênese do AP.

\section{Agradecimentos}

Agradecemos à Fundação de Amparo à Pesquisa do Estado de São Paulo (FAPESP) (Processo FAPESP 2011/23366-5 e 15/07304-0) pelo apoio financeiro e à FAEPEX (bolsa regular de Iniciação Científica) que viabilizaram a execução deste trabalho. Além disso, agradecemos ao Hospital de Clínicas da Universidade Estadual de Campinas, ao Departamento de Anatomia Patológica da Faculdade de Ciências Médicas da Universidade Estadual de Campinas e ao Laboratório de Patologia Molecular (LAPMOL). 